\title{
「想像の場」としてのインゴルシュタット 一『フランケンシュタイン』を生んだ科学と想像の場-†
}

\section{柳原 伸洋 *}

\section{1. はじめに}

ここ数年，わたしの心を捉えて離さないドイツの都 市がある．南ドイッ・バイエルン州に属するインゴル シュタット (Ingolstadt) という街だ。同市との「出会 い」は, 過去に働いていた大学での卒業論文指導を通 じてだった，ドイツ現代史，とくに空襲研究に従事す る筆者は，以前から空襲被災都市のひとつとして同市 の名は見知っていた ${ }^{1}$. しかし, 同市の放つ歴史的想像 力の魅力に気づかせてくれたのは学生だった，彼女の 卒業論文は,「近世ドイッの魔女迫害 一インゴルシュ タット大学の役割を中心に一」と題され，16〜17 世 紀の魔女裁判を推進した者と批判した者が学んでいた インゴルシュタット大学をテーマに, 同大の講義記録 (ドイツ語文献)などを利用した論文だった。学部学生 の卒論のレベルをはるかに超えた力作であり, 当然の ことながら高く評価された。

私はこの学生の卒業後も, 読書や資料収集の際に「イ ンゴルシュタット」という文字列に自然と意識が向く こととなった。そして，そこに「偶然の重なり」が立 ち現れてきたのである。具体的には, 1528 年に「実在」 のファウスト博士が追放された都市，そのほぼ同時期 に錬金術研究者パラケルスス (1493-1541 頃) が奇蹟を 起こしたとされる都市, 1776 年に秘密結社イルミナテ イが結成された都市, そして 1818 年に出版された小説 『フランケンシュタイン』の舞台となった都市という重 なりである。本論では，この「偶然の重なり」はけっ して偶然とはいえないことが明らかになるだろう。こ こに関係しているのは，インゴルシュタットの都市史 であり，同都市が生み出した歴史的な想像力である.

さて，筆者に与えられた「フィクションとテクノロ

$\dagger \quad$ Ingolstadt as "the Space of Imagination": The Place of Science and Imagination Which Created "Frankenstein" Nobuhiro YANAGIHARA

* 東京女子大学現代教養学部歴史文化専攻

Department of History, School of Arts and Sciences, Tokyo Woman's Christian University
ジーというテーマを人文社会科学の専門知から書く」 という使命は果たさねばならない。これは，本稿の 3. で扱う小説『フランケンシュタイン』と都市インゴル シュタットの部分に結実してくるだろう。しかしまず は，インゴルシュタットの歴史を押さえつつ都市の特 徵を把握し, 歴史的想像力の源泉としての同市の特性 に迫りたい，そして，「記憶の場」を嗃矢とする昨今の 記憶文化研究さらにはフィクションをめぐる諸研究な どを活かし，フィクションとテクノロジーとの交差を 歴史学的な知見から掘り起こす実験をしてみたい.

\section{2. 前提としての「記憶の場」研究}

都市とフィクションという切り口から，どのように 「テクノロジー」という扮題に切り込むのか不安を覚え る読者も扮られるだろう。ここでは，人文社会科学の 先行研究をひとつ噛ませる必要がある。それは「記憶 の場 Les lieux de mémoire」研究である。

フランスを発信源として 1980 年代半ばから,「記憶 の場」の研究が活性化していく、研究を搴引したピエ ール・ノラの「記憶の場」とは, 記念碑や人物そして 神話など,「集合的記憶 collective memory」として構築 され語られてきた対象の研究成果である $[1,2]$. 集合 的記憶は，個人の記憶ではなく，社会が共有する記憶 （祭日，記念式典，歷史展示など）を指す概念である。 これは,「物理的な場所」のみに拘束される概念ではな い.たとえば,「ジャンヌ・ダルク」をはじめとして, 「ツール・ド・フランス」や「ガストロノミー (美食)」 もまた，歴史的に象徵的な力を有し集合的記憶として 構築されてきた。 1990 年代後半から, 日本においても 「記憶の場」に関わる研究成果が出されていく，筆者自 身もまた，空襲を中心に記憶の文化史研究に取り組ん できた（参考文献の柳原の諸研究を参照）.

1 ドイツでは, 都市史 (郷土史) としての空襲研究はたいていの 場合, 都市ごとに出版されている. インゴルシュタットの場合 はたとえば, H. Fegert: Luftangriffe auf Ingolstadt, Kösching, 1989. 
本稿は,「記憶の場」研究に棹さしつつも, それを別 角度から眺めようとする意図がある。「記憶の場」と は先述のように，現在へと連なっていく集合的な記憶 を指し示す概念だが，本研究では「場＝都市」そのも のを前景に押し出し，「場」としてのインゴルシュタ ットがフィクションの舞台となる事例を考察する。つ まり，同市が過去に有した「想像の場」としての影響 力を分析する。具体的には，インゴルシュタットが 19 世紀初頭に放っていた「想像の力」と小説『フランケ ンシュタイン』との関係について考察する.

本研究は「記憶の場」を現在への連続性ではなく断 絶性の観点から更新する意罒がある. 後に示すように, いまやこの「想像の力」は, インゴルシュタットでは すでに失われてしまったといえる。現に,『フランケン シュタイン』は知られているが, 同作の舞台がインゴ ルシュタットだということを想起する人は少ないだろ う².たとえこのことを記憶していたとしても，なぜ 19 世紀前半に書かれたフィクション作品『フランケン シュタイン』がインゴルシュタットを舞台としたのか については，説明を要するだろう。本稿はこの問いへ のひとつの答えである.

インゴルシュタットが有していた想像性は, 本誌を 発行する「日本知能情報ファジィ学会」のテーマであ る人工知能・科学などのキータームとも密接に結びつ いている。このように, やや入り組んだ問題設定のも とでの歴史学叙述がうまくいくかどうかは分からない が挑戦してみたい.

\section{3. インゴルシュタット大学史と「脅威」 との相関}

\section{1. インゴルシュタットの概要}

インゴルシュタットはミュンヘンとニュルンベルク とのあいた，そしてドナウ川沿いに位置している。古 代ローマ時代にはリーメスと呼ばれる「ローマの境界」 付近の要塞となった。「インゴルシュタット」という都 市の名は, 西暦 806 年に古文書にはじめて登場すると される。

6 世紀以来, この地を治めていたのはバイエルン公 であった. バイエルン公ルートヴィヒ 9 世(1417-1479) によって，この都市に公国最初の大学が設立されたの

2

なお, ツーリズムの観点からはインゴルシュタットでは「フラ ンケンシュタイン・ッアー」が開催されており, 2018年の『フ ランケンシュタイン』誕生200周年に際してのイベントが各種 用意されている. 参考：https://www.ingolstadt-erleben.de/ frankenstein/geschichte/frankenstein-stadt/ [accessed June 15, 2018]
は 1472 年のことだ。 大学設立によって,インゴルシュ タットはヴィーンやプラ八にならぶ,「カトリック精神 に満ちた大学」[3], そして「カトリックの砦」となっ た [4]. この理由は次節で説明したい.

一般的にカトリックには「守旧的な」イメージがつ きまとうが, 15 世紀にはカトリック内部での改革運動 が盛り上がっていた[5]. この改革に大学は大きく寄与 したのである。ほかにも，小説『フランケンシュタイ ン』の着想に決定的な影響を与えたであろう解剖学研 究所が 18 世紀前半に設置されるなど [6], インゴルシ ユタット大学は近世から近代へと移行していく時期の 科学を支える地位を占めていた。

だが，キリスト教改革の流れは，カトリックと対立 するかたちで 1517 年の「宗教改革運動」として結実す る. 先述のように, インゴルシュタット大学はカトリ ック側の改革の中心地であったことから, 反プロテス タントの橋頭堡となった。たとえば, マルティン・ル ター（1483-1546）を厳しく批判したヨハネス・エック (1486-1543) は, インゴルシュタット大学の神学教授 だった。

しかし，これだけでは「なぜ，インゴルシュタット に大学が設置されたのか？」，そして「なぜ，カトリッ クの些なのか？」を説得的には語れていない，次節で は,「実在」のファウストに言及しつつ, その理由を掘 り起こしていこう.

\section{2.「イスラームの脅威」と大学設立}

前節では, インゴルシュタットが大学設置後に「カト リックの砦」となったと書いた。実は，この「砦」と いう表現は，より具体的なイメージをともなって語ら れていた，それは「イスラームの脅威」である。1453 年にコンスタンティノープルを陥落させ 16 世紀には ウィーンを包囲するまでに至るオスマン＝トルコ帝国 は,キリスト教世界に激しい動摇を呼び起こしていた。

では, 第一次ウィーン包囲の前年である 1528 年にイ ンゴルシュタットで起きた「事件」について述べてお こう。ここに登場する人物は, ゲーテの著作『ファウ スト』で知られるファウスト（歴史的にはファウスト ウスとも)である。6月17日の市参事会議事録によれ ば，ファウストはインゴルシュタットからの追放を命 じられている [7]. これは先述の「イスラームの脅威」 と結びついた事件だった。

では以下に, 日誌資料を引用しておこう。これは, フ アウストについてインゴルシュタット近郊の修道院の 代表的な立場を務めたキリアン・ライプ（1471-1553） が書き残した日誌である。 
（前略）ファウストスは, 1528 年 6 月 5 日に「も し太陽と木星が扮なじ星座のもとにとどまるなら ば，預言者（つまり彼のような人物もそのひとり ということだろう）が生まれるであろう」と言っ た。彼は，自分がケルンテンの国境ハレシュタイ ンという場所のヨハネ騎士団の上級騎士修道会員 ないし教師であると主張した $[8,9]$.

引用の前半部分もまた当時の「科学としての占星術」 を表していて興味深いが,ここでは後半に着目しょう。 ケルンテンとは, オーストリア・ケルンテン州の辺り を指し，現スロベニアとの国境に位置している。そし て, 同地はオスマン=トルコの脅威にさらされていた. なお，ハレシュタインという都市は存在せず，ハレン シュタイン（現シュタイアーマルク州）ではないかと 考えられている [10]. また, 歴史上のファウストがケ ルンテンのヨハネ騎士団に所属していた可能性は低い とされる [11].

ここで重要なのは, ファウストの発言の真偽ではな い.「ヨハネ騎士団」というタームである. 彼らはイス ラーム教徒と敵対する騎士修道会 ${ }^{3}$ であり，1522 年に オスマン帝国のスレイマン大帝によって, 本拠地のロ ドス島から追われていた。ここでは，彼が述べたとさ れる言葉が, 16 世紀前半のインゴルシュタットやその 周辺，そしてドイツ地域を覆っていた雲囲気を反映し たものだという点が重要なのである.

さらに文化史的にも捕捉して抢こう。ドイッ・ルネサ ンスの代表的な画家アルブレヒト・デューラー（14711528)はインゴルシュタット近くの都市ニュルンベルク で活躍した画家・数学者だが, 1508 年の油彩画「一万 人のキリスト教徒の殉教」では, 虐殺の指導者の頭に夕 ーバンを巻くことでオスマン帝国の脅威を想起させる 描き方をしていた。これは, デューラーの家族がイスラ ーム勢力が迫りくるハンガリーから逃げてニュルンベ ルクに移り住んでいたことと無関係ではないだろう.

このような歴史的背景のもとに，インゴルシュタッ 卜大学は「キリスト教的な知」の最先端として発展し ていった。しかし，17世紀にはイギリスを中心に科学 革命が起きると，大学という知の組織はキリス卜教的 な宗教観に基づいた「学」と, 実験・観察に導かれた 科学的な「学」の両者に分裂していく.インゴルシュ タット大学は, このふたつの「学」が入り交じり, 拮 抗する場でもあった。

3 騎士修道会は, 十字軍の遠征時に組織された, 各地の住民の 保護・自衛·戦闘などを担ったカトリックの武装組織である.

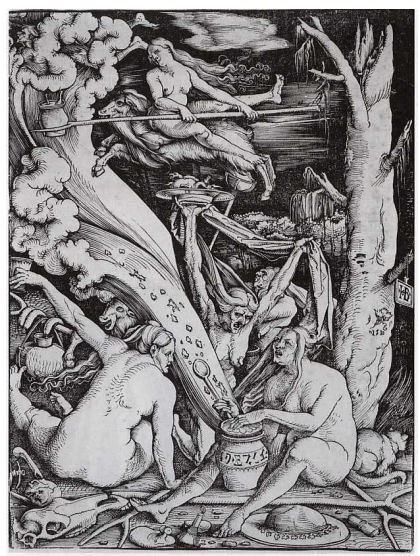

図 1 「魔女の宴」1510 年頃

\section{3. 魔女裁判と大学の知}

デューラーは, 1500 年頃に「魔女」を描いたことで 知られている.さらに, 彼の弟子ハンス・バルドゥン グ・グリーン (1485-1545) は,「魔女の宴」という版 画を製作している（図 1)。「恐怖」を帯びたこの版画 は，魔女イメージの代表的存在としてドイツ語圈を中 心に流布していくのである.

ルネサンスとは「文芸の復興」であり, 知の力によっ て世界を照らし出すという啓蒙思想とも通じていた. また，プロテスタントを支持したデューラーは，ル夕 一を支援し，彼の肖像画も残している，だが，世界を 照らすこの運動は, 同時に「暗さ」を際立たせる効果 があった点も看過できない. そして, 宗教改革や啓蒙 主義のコインの裏側として魔女迫害が横行し, 多くの 犠牲者を生んでいった。以下，インゴルシュタット大 学を中心に魔女裁判について述べていこう。.

インゴルシュタット大学がカトリック的な宗教観を 保持・強化する場であり, 同時に科学発展の場でもあ った点は, 魔女裁判の時代に, 同大学が果たした役割 について考えれば明らかとなる。

いわゆる「魔女狩り」は，ヨーロッパ中世的なイメ ージとセットで語られることが多いが, 実際には近世 と呼ばれる時代に大規模化した現象である。魔女迫害 の盛期は 16 世紀末から 17 世紀前半にかけてだった 民衆から訴えが出され, 各地方の司法が魔女の疑いの ある人物（女性とはかぎらない）を裁くという制度は， 近代司法システムにもつながっている [12].

宗教改革に対抗する大学としてのインゴルシュタッ 卜大学は, 前述のルターの論敵ヨハネス・エックが死 去する 1543 年以降, イエズス会 ${ }^{4}$ 色の濃い大学となっ 
ていく、たとえば，イエズス会の創設期の重要人物ぺ トルス・カニシウス（1521-1597）は, 神学教授として インゴルシュタット大学の学長や副総長を務めた人物 だった，魔女の歴史研究の第一人者であるヴォルフガ ング・ベーリンガーは，カニシウスを魔女迫害の広範 囲化を加速させた重要人物だと見ている [13].つまり, 各地方で応用可能な魔女迫害の「科学的」な理論が, 大学で生みだされたのである。

たとえば，ケルン選帝侯エルンスト・フォン・バイ エルン（1554-1612）と協働司教のフェルディナント. フォン・バイエルン（1577-1650）は, 1607 年に魔女裁 判手続きの手続きを規定したことで知られている。前 者はインゴルシュタットにてイエズス会士の教えで神 学を学び, 後者は 1595 年頃にインゴルシュタット大 学を修了した人物である。直接的に同規定がケルン司 教領の魔女迫害を急進化させたわけではないが，規定 によって地方裁判の遂行が容易化したことは見過ごせ ない [14]. 魔女裁判を中央機関の強力な監督下に置く のではなく，大学が設置されているような都市から派 遣された「学識法曹」に裁量権が委ねられていた。こ の「非中央集権化」が魔女裁判増加の要因のひとつた と考えられている [15]. 実際に, ケルン選帝侯領では 1615 年頃から裁判件数が増加し 1628 年から 31 年にピ ークを迎えたとされる，本論にとっては，選帝侯がイ ンゴルシュタットで学んだ人物だった点とともに,「学 識法曹」の活躍も指摘しておきたい.

また, 帝国自由都市ケルンは多くの修道院や印刷業 者を擁する大都市だった. 大量の魔女迫害の後に, 裁判 の賛否に関する出版物が多く世に出された，イエズス 会士のフリードリヒ・シュペー（1591-1635）は，魔女 裁判に対する批判として『犯罪に対する警告』を 1631 年に出版している。同書で彼は, 裁判が各地域の個々 人の利害対立をもとになされている点を指摘した。

この魔女裁判を批判する側にもインゴルシュタット が関わっている. 裁判の不当性・不合理性を訴えたア ダム・タナー（1572-1632）は，インゴルシュタット大 学で学んだイエズス会士だった。ただし, タナーは魔 女の存在に否を唱えたわけではない。あくまで魔女裁 判の不合理そして迫害の犠牲者への哀れみを表明した のである [16].

このように,「カトリックの砦」としてのインゴルシ ユタット大学は, 大学ゆえに魔女裁判を支える人物を 生みだしたが，大学ゆえに「合理的な思考法」を身に

4 イエズス会は, カトリック側の宗教改革運動の一つ. フランシ スコ・ザビエルもその一員であり, 世界中でカトリックの布教 活動に従事した.
つけて魔女裁判の正当性に対する反論を提出する人物 も生みだしたこととなる。

\section{4. 「フランス革命の脅威」とイルミナティの結 成, そして大学移転}

宗教と科学の中心地であったインゴルシュタット大 学は, 1800 年にバイエルン公国の東部の都市ランッフ ートに移されることで，いわば廃校となってしまう。 同時代のドイツ地域の「脅威」は，今度は西側から到 来した。 フランス軍のライン渡河の報である。ささらに 1799 年にインゴルシュタットはナポレオンの先遣隊 に侵入されている [17].

フランス軍がライン川に迫った原因は, 18 世紀後半 の世界史上の出来事にその理由を求められよう。 それ は 1789 年のフランス鞈という市民革命であり, その 後に展開されたフランス鞈戦争そしてナポレオン戦 争である。この市民革命では, 合理・知性にもとづい て世界を照らさんとする啓蒙主義の普及が大きな役割 を果たしている。

啓蒙主義が行き着いたひとつの到達点は, 実はイン ゴルシュタット大学にあった.まずは,この極点に至る 経緯を説明したい. 18 世紀には啓蒙主義運動の台頭に よって学内のイエズス会の影響力は弱まり [18], 1773 年のイエズス会禁止令によってその勢力はさらに弱く なっていた. 実は, インゴルシュタット大学はイエズス 会禁止令前からも啓蒙主義的改革を試みていた [19]. これらの改革が成功しなかったのは, 時代の特色であ る「啓蒙の精神」を圧迫するイエズス会の精神的雲囲 気が強く残存していたからだといわれる [20]. だが, 前述したようにイエズス会の支援するインゴルシュ夕 ット大学は「カトリックと科学」を推進する機関だっ た、ゆえに,「啓蒙の精神」と完全には対立せずに融合 した面もあったのである。

この一例を，イエズス会教育を受けて育ったインゴ ルシュタット大学・教会法教授のアダム・ヴァイスハ ウプト（1748-1830）に求めることができよう。1776 年, 彼は啓蒙主義的な秘密結社イルミナティを結成し た。この結社は、いわゆるフリーメイソンの一種であ る、ただし,より一層, 啓蒙とモラルのために活動す る目的を持ち,フリーメイソンを急進化させた団体だ と位置づけられる [21].「バイエルン啓明結社」とも 呼ばれ，知の光によって社会を変革していこうとする 者たちの結社だった。最盛期のメンバーは 700 人を数 え, 官吏 ·大学教授 ·聖職者・貴族に広まっていった [22]. その後, 1785 年にはドイツ国内の禁止・弾圧に よって解散させられるが, 1789 年のフランス革命前夜 の啓蒙運動として, 明らかに社会革命的な理想を抱い 
ており, フランス鞈に影響を与えた組織とされた。

イルミナティには，トム・ハンクスが主演した映画 『インフェルノ』（ロン・ハワード監督，2016年）など で描かれたような院謀論がつきまとう。たとえば, フ ランス革命は啓蒙主義者とイルミナティの陰謀による ものとし, 神の秩序に対する反逆として非難されもし た[23]．また,イルミナティの目的を「死者とも交流」 だと断じる意見もあり [24], この点は, 小説『フラン ケンシュタイン』の舞台としてインゴルシュタットが 選ばれた理由として重要だろう。実際に，作者メアリ ー・シェリーは，夫である詩人のパーシー・シェリー の影響からイルミナティとフランス革命との関係性に 興味を寄せていたことが知られている [25].

しかし歴史の皮肉というべきか，あるいは必然とい うべきか，啓蒙主義の理性はフランスにおいて革命を もたらす一要因となり, さらにその市民軍はインゴル シュタットを含むバイエルン地域を脅威にさらした。 結果として，大学もまた東側のランッフート市に移転 された。その後，1806 年にバイエルン王国が設立さ れ，大学組織は王国の首都であるミュンヘンに移設され

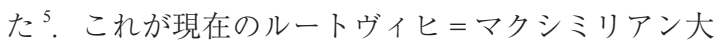
学, つまりミュンヘン大学である.

大学がランツフートへ移動してしまった 1800 年以 降，インゴルシュタット市は大学都市から軍事都市へ と変容することで生き残りをかけた。1 1861 年には人口 2 万人の約 6 割は軍人となった [26]. この軍事都市イ ンゴルシュタットはヴァイマル共和国時代に，マリー ルイーゼ・フライサーの戯曲「インゴルシュタットの 煉獄」として舞台で演じられることとなるが[27], こ れは本稿のテーマとは異なるので稿をあらためたい. 19 世紀に, インゴルシュタットは, 大砲製造などの軍 需産業を中心に発展する。して現在は，世界的に知 られる自動車メーカーのアウディの本社が置かれ，失 業率がドイツでもっとも低い都市として知られている (2018 年時点).

\section{4. 魔術と科学の交差としての『フランケ ンシュタイン』}

\section{1. あらすじ}

『フランケンシュタイン』は今な拈多く読まれ,豊穣 な研究成果も出されている小説作品である。まずは物 語の概要を記しておこう.

ジュネーブで生まれ育ったヴィクター・フランケン シュタインは, インゴルシュタットで学び, そして生

5

1980年に, カトリック大学アイヒシュテット=インゴルシュタッ トが設立された

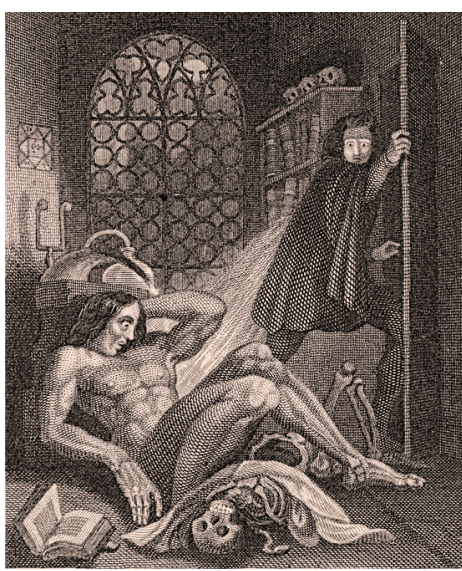

図２『フランケンシュタイン』(1831 年版) の内表紙

命の秘密を探り当てて人造人間（＝怪物）を生みだす， しかし，フランケンシュタインはその醜さゆえに怪物 を見捨て、ジュネーブに戻ってしまう。一方，怪物は インゴルシュタット近郊の森で言葉を覚えて知性と感 情を獲得した。しかし，森に住む家族からの拒絶に絶 望し, 怪物は生みの親であるフランケンシュタインの 身の回りの人びとを殺害することで, 彼に復讐してい $<$.

以上のあらすじは，映画作品などでも基本的には踏 襲されている。しかし現在，一般的には「怪物＝フラ ンケンシュタイン」という誤解が広まっているといえ るだろう。原作の「怪物」はインゴルシュタット周辺 の森で，文字を覚え，人間存在の愚かさを理解し，そ れを主人公のヴイクター・フランケンシュタインに突 きつけてくる。つまり,「怪物」は図 2 のように, 恐ろ しい容姿ではあるものの知性を有する存在として描か れている.

また，原作が複数の語り手によって物語られている 点など知られていないことも多いだろう。つまり，北 極点を目指す探検家ウォルトンという人物の語りのな かに, フランケンシュタインの語りが入り込み, さら にその中に怪物の語りも入り込んでいるという三重構 造になっている。 これは極地探検という冒険の危うさ と, フランケンシュタインの人造人間創造という科学 の危うさを重ね合わせる効果がある。物語では，無理 を押して探検家ウォルトンは北極点に向か抢うとする が，怪物に追われて疲弊し臨終のときを迎えようとし ていたフランケンシュタインは最初, ウォルトンの好 奇心に取り憑かれた無謀さを難じる。しかし, 最後に フランケンシュタインは探検続行を支持し, 彼の, そ して科学者の性懲りなさが強調されるのである. 
このような複雑な物語の構造に加えて, メアリー・シ エリーは怪物創造の原理をはじめとして各所でぼやか して書いているので, 逆に読者の想像力を喚起し様々 な研究がなされるようになった。たとえば、ジェンダ 一的観点, 植民地主義と異者への恐怖, サイエンス . フィクション，そしてその後の受容史などである。し かし，本稿の試みのようにインゴルシュタットという 怪物創造の場を「想像の場」として捉えたものはない.

原作者のメアリー・シェリーは, 1816 年 6 月あたり から『フランケンシュタイン』を執筆しはじめたと考 えられる.なぜなら,この小説の着想は 1806 年のジュ ネーブの別荘での怪談創作で生まれたからである。こ の別荘の持主は著名な詩人のバイロン (1788-1824) で あり, メアリーの夫で詩人のパーシー・シェリーも怪 談創作会に参加していた。他にも医師ジョン・ポリド リ（1795-1821）も参加し,「吸血鬼」の着想を得て後 に出版し，これが吸血鬼小説の始原とみなされている [28].

\section{2. 科学と魔術のあいだ}

『フランケンシュタイン』は現代 SF の祖型とされて いる。アイザック・アシモフ (1920-1992) は, SFに おける「ロボットが人類を破滅に導く恐怖」を「フラ ンケンシュタイン・コンプレックス」と名づけた [29]. また，彼の作品『われはロボット』に登場する「1.人 間に危害を加えない，2. 命令に服従せねばならない, 3. 前二項に反しないかぎりで自己を防衛せねばならな い」という「ロボット工学の三原則」も, フランケン シュタインの生みだした怪物に起因するとされている [30].

『フランケンシュタイン』のエピグラフには, ミル トン『失楽園』(1667 年) からの文章が引かれている. これは同小説の本質であり, 怪物からの問いかけであ る. 科学とフィクション, そして人工知能研究をはじ めとして近代以降の科学への警句ともなっている.

創造主よ，土塊（つちくれ）からわたしを人の かたちにつくってくれと頼んだことがあった か?

暗黒からわたしを起こしてくれと，お願いした ことがあったか？

このように『フランケンシュタイン』は,「人」を 人間の手で創造することへの意味を深く問うた作品だ った。繰り返しになるが, 小説『フランケンシュタイ ン』の怪物は愚鈍ではなく, 知性を習得し, 創造主で あるフランケンシュタインを問い詰める存在である.
さらに「現代のプロメテウス」という副題も、『フラ ンケンシュタイン』の科学とフィクションの関係性を 考えるうえできわめて重要だ。ギリシア神話のプロメ テウスは, 粘土と水から人間を創り出し, ゼウスの稲 妻から盗んだ火（これはつまり知とテクノロジー）を 人に与えた。 ゼウスはプロメテウスの行為に激怒し， 彼をコーカサスの山中の岩場に縛りつけ, 鷲に肝臓を 豚ませたのである [31]. プロメテウスには二つの象徴 性がある。一方では人類の救い手として, 他方で神へ の裏切り者としての側面であり, これらは「科学者」 を体現しているといえるだろう．

また，主人公フランケンシュタインは，啓蒙主義の 影響を色濃く受けている点にも注目したい.

父が細心の注意を払って教育したため、わたし の頭は超自然の恐怖に取り憑かれないように なっていました。ですから，迷信に震えたり， 亡霊を怖れた記憶はまったくありません。闇が 想像力に影響を与えたこともないし，墓場も， わたしにとっては, 生命を失った肉体を迎える 場所でしかありません [32]

このように，超自然的な力を知によって克服してい るさまが描かれている。ささらに本作の着想にも, 19 世 紀初頭の科学発展が関わっている.

この物語のもととなったアイデアは, ダーウィ ン博士及びドイツの一部の生理学者のあいだで, 不可能ではないとされているものである [33].

これは,『フランケンシュタイン』の初版（1818 年） の序文の出だしだ。この「ダーウィン」は, 進化論の チャールズ・ダーウィンの祖父エラズマス・ダーウィ ン（1731-1802）である。そしてこの一文を書いたの は，夫のパーシー・シェリーだ，彼は，この後に「こ の話（『フランケンシュタイン』）に書かれている興味 深い出来事は, 幽霊や魔法を報告しただけの話にある ような欠点を免れているのである」と続ける [34].

この物語の書かれた 19 世紀の前半, イギリスは産業 革命によって急激に社会が変化していた時代だった， オカルト的なものが科学の力によって排除されたが, 他方で啓蒙のプロジェクトとしての近代科学はまた， 「オカルト的な知」を強化する場合もあったのである.

これは 100 年後の 20 世紀前半にいたって,かのコナ ン・ドイル（1859-1930）が神秘主義的な心霊主義者だ ったことと軌を一にしている。っまり, 科学の力は, 「魔法」を授けると考えられていたのである。 
他の例を挙げれば, ドイツでヴィルヘルム・レント ゲン（1845-1923）がX線を発見しドイツ中で講演会を 行った後に，X線によって人の心も透けて見えるとい う未来観に人びとが取り憑かれたように, である [35]. このように，科学主義とオカルティズムは，あるとき は対立し，あるときは歩みをともにしてきた。

ヴィクター・フランケンシュタインも「科学の進歩」 だけにとらわれた人物としては描かれていない，彼を して人造人間を創らしめた研究動機とは何だったのだ ろうか. これに関しても多くの文学研究者が指摘する ように, インゴルシュタット大学入学決定の後にフラ ンケンシュタインの母親の死が描かれ，それによって 一時中断となっていた大学入学へと話は進んでいく. 彼は,「母の死」を契機として, 生と死, そして生命創 造への欲望を抱いたのである.

そして学術的には,「想像」を大きな原動力とする錬 金術への傾倒から，それを動機の重要なエナジーとし て「近代的な科学」を用いる点にフランケンシュタイ ンの研究の結実がみられるのである。

科学史研究者のクロスビー・スミスは, 以下のよう に指摘する。

「熱に浮かされた狂気にとりつかれ，わたしは理 性を備えた生き物を造り上げました」。瀕死の ヴィクター・フランケンシュタインはウォルト ンにそう告白する。メアリー・シェリーのこの 傑作を形作っているのは，主に，二つの力の間 の激しい拮抗である。すなわち, この小説は, 表面的には啓蒙時代のイデオロギーに基づく「理 性」を描いているが, その「理性」は, 自然や 人間存在の内にある, より梁く, より暗い力に よってつねにおびやかされているのである。ロ マン派の詩人たちは, この深く暗い力に引きつ けられていたのであり, うら若いメアリーもそ の文化を共有していた [36].

つまり，主人公のフランケンシュタイン自身も前近 代的な錬金術と近代的な科学との間の存在である，彼 は, インゴルシュタット大学で学び, 古き錬金術など の学問について破棄するように，化学者のクレンぺ教 授に諭される。しかし，フランケンシュタインにはど こか納得できない気持ちがあった，小説内から以下の 部分を引用しておこう。

近代自然科学の果たす役割に, 軽茂の念さえ持っ ていたのです．科学の大家たちが不滅の力を追 い求めていた時代は, その目論見が無䭾に終わっ
たとはいえ，やはり壮大なスケールがありまし た、今では状況が変わってしまい, 研究者のめ ざすものが限定され，科学への興味を育んでく れたはずの夢を，毛嫌いするようになっていま す，限りのないスケールを持つ幻想を捨てて， ほとんど価值のない現実を受け入れよと迫って いるのです [37].

青年フランケンシュタインに多大な影響を与えた人 物として登場する, インゴルシュタット大学のヴァル トマン教授は，彼にこのように語っている.

こうした人たち（パラケルススなどの錬金術研 究者）の尽きることのない情熱があったればこ そ, 現代の科学者の知識が築かれたのですから, その意味では感謝すべきなのです。新しい名前 をつけたり，一貫した分類を招こなうといった 楽な仕事は，わたしたちに残されたのですが, 事実を明るみに出す上で彼らが果たした役割に は大きなものがありました，天才たちの努力が たとえ間違った方向に向かっていたとしても， 究極的に人類の確固たる利益となることは間違 いがないのです [38].

これがフランケンシュタインを捉えた「想像」であ り,ファウスト的な狂気, つまり知識への情熱と傲慢 であった [39]. もち万ん, 彼自身もヴァルトマン教授 の言葉は,「(自らを) 破滅させる運命の言葉」だと予 期している [40].

\section{3. インゴルシュタットとの交差}

ここで明らかになったことは, 主人公の科学者フラ ンケンシュタインの知の態度とインゴルシュタットの 知の環境が重なり合っているという点である。では, なぜメアリー・シェリーはインゴルシュタットとその 大学を作品の舞台としたのだろうか．この問いには歴 史学や人文科学研究では, 完全に答えることはできな い、そこで，「はじめに」で記したように，本稿では 「想像の場」としてのインゴルシュタットと小説『フ ランケンシュタイン』との関連性を通して考えていこ う.

まず，作者のシェリーがインゴルシュタットを訪れ たという記録はなく，想像だけで小説を著した可能性 が高い. 大学設立以降のインゴルシュタットでは, 先 述のようにキリス卜教と学問知の拮抗が見られた。そ してファウストだけではなく, パラケルススが奇蹟を 起こした都市だとされている点も重要だろう [41, 42]. 謎の多い人物だが, パラケルスス（後の別称でホーエ 
ンハイム) こそは, 錬金術によって人造人間「ホムン クルス」の「製造」を唱えた人物であった。『フランケ ンシュタイン』にも, パラケルススは作品全体で 4 回 の言及がある。そして、インゴルシュタット大学に 18 世紀前半に設置されていた解剖学研究所は, 物語の核 と密接に結びついている.

次に, 同作では「17 年」としか表記されていない が，1792 年から 1799 年にかけての物語だと考えられ ている [43]．これは，怪物がヴォルネーの『諸帝国の 滅亡』（1791 年）を読む描写があることなどから分か る。また, 1790 年代後半には, ドイツ語圈（神聖ロー マ帝国の領域内)に拉よそ40 以上の大学が存在してい た，その中から, 著者は「消えてしまった」(物語の時 間では「消えつつある」) 大学であったインゴルシュタ ット大学を舞台としたのである.

18 世紀後半を生きたメアリー・シェリーが，どの程 度まで時代の影響を受けているかについても多数の研 究が存在する。彼女は, 急進的な社会思想家で小説家 の父ウィリアム・ゴドウィンと女権拡張論者で小説家 の母メアリー・ウルストンクラフトとのあいだに生ま れ，開明的な考えをもっていた，そして，18 世紀後半 のヨーロッパの大事件であるフランス革命を期待と不 安をもって捉えた同時代の知識人のひとりだった。フ ランス革命やそれにいたる啓蒙思想が，この小説に多 大な影響をおよぼしていることはすでに指摘したとお りである。

また，インゴルシュタット市には「イスラームの脅 威」の影響を受けながら科学の最先端組織である大学 が建てられたことも指摘した，次に，市民革命という 啓蒙のプロジェクト，つまり「フランス革命の脅威」 によって, 結果的に都市から大学は姿を消すことにな る.

インゴルシュタット大学の「先端性」と「危機」が 小説『フランケンシュタイン』と重なり合っている. 主人公が学んだのはインゴルシュタット大学であり, 怪物が生まれたのもまた同市だった。繰り返すが，作 者が同市を怪物創造の場として選んだ理由は詳らかで はない.しかし，当時すでにドイツ語圈（神聖ローマ 帝国領域内)で拉よそ40 以上の大学が存在していたな かで，同大学を選んだのはイエズス会的な「カトリッ ク的な科学」と解剖学研究所をはじめとする「合理主 義的科学」との拮抗，そして同時代的に発生していた

先述したように, インゴルシュタット大学の移動はフランス革 命軍の脅威であり, 1790年代にはまだ趨勢は決していなかっ た.しかし，1800年の大学移設を知る作者シェリーからは「消 えゆく」と見えていても不思議ではないだろう。
啓蒙主義の発展（イルミナテイ）をみた都市だった点 は看過できないだろう。インゴルシュタットは, 19 世 紀初頭に扔いて、『フランケンシュタイン』の舞台とし て最適な想像性を放っていた都市だったのである。

\section{4. インゴルシュタットの「消失」}

『フランケンシュタイン』は 1818 年の公刊以来，イ ギリスを中心に多くの人びとに読まれたが，最初にこ の人気・認知度を押し上げたのは演劇であった。 とく に後の映像作品でも多用される「怪物創造」の瞬間に フランケンシュタイン青年が放つ台詞「生きている!」 は, 1823 年の演劇『フランケンシュタイン』に拈ける 台詞だった [44]. 劇では, 装置としての「舞台」が重 要視されるので都市「インゴルシュタット」の特性よ りも, フランケンシュタイン博士の研究室（実験室） などの装置が強調された。

21 世紀を生きる私たちの「フランケンシュタイン」 イメージは, 1931 年のアメリカ映画『フランケンシュ タイン』に多大な影響を受けている。つまり,「怪物= フランケンシュタイン」という誤解は, この映画によ って一気に広まったのである。それはたとえば, 藤子 不二雄の漫画『怪物くん』に出てくる「フランケン」 のようなイメージである。この「怪物＝フランケンシ ユタイン」イメージが扱われた作品では, インゴルシ ユタットという都市は姿を消している。

この科学者「ヴィクター・フランケンシュタイン」 消失の理由を, ヴイクトリア朝文学を研究するルイス。 ジェームズは，以下のように述べている.

1930 年代までには, 科学者についての一般的な イメージは,メアリ・シェリーの時代とは完全 に変わっていた，科学技術が目覚ましい進歩を 遂げている時代に, 科学者がなにか間違いを犯 すなどという設定にするわけにはいかなかった [45].

このような設定変更において, 都市インゴルシュタ ットという魔術・科学の先進都市を登場させる必要性 は希薄になった。怪しげ, かつ半魔術的な実験室での 怪物の「創造」は，21 世紀を生きる我々に染みついた フランケンシュタイン・イメージである。しかし, 18 世紀末を舞台にし，19 世紀初頭に書かれた原作の『フ ランケンシュタイン』は,「最新」の科学的知見によ って, 怪物を創造した「現代のプロメテウス」として のヴィクター・フランケンシュタインを登場させてい た。

1931 年の映画『フランケンシュタイン』は, インゴ ルシュタットを消し去り, 科学の過誤を消し去るため 
に，フランケンシュタイン博士の助手を描いている. この「患かな」助手が, 誤って「犯罪者の脳」を博士 に渡してしまうことで, 怪物は悪の存在になる。繰り 返すが,メアリー・シェリーの書いた「怪物」は知性 的であり，欲望に取り憑かれたフランケンシュタイン 博士を諭すような警句を放つ存在なのである。

1994 年に制作され，日本では翌年に公開されたケネ ス・ブラナー監督『フランケンシュタイン』は「原作 に忠実に」をモットーにして作られたので，インゴル シュタットが舞台として登場する。しかし, 城壁都市 でペストが大流行する，混沌とした怪しげな「中世都 市」のような描写だ。インゴルシュタットの先端性が 強調されることはない.

\section{5. おわりに}

歴史学研究の王道は, 史料分析によって歴史的な位 相を探るやり方である。本稿は，そこから逸脱しなが らも記憶の場研究に刺激を受け, 歴史研究の立場から フィクションを支える「想像の場」を探ってみた。と くに, インゴルシュタットというドイッの一都市の歴 史を中心に「想像」と「科学」について考察すること で,フィクションの想像力の源泉となった「想像の場」 として同市を捉えてみた。

「想像の場」としてのインゴルシュタットは, 大学創 設の 15 世紀以来, 「イスラーム」への恐怖，カトリッ ク・プロテスタントの対立, そして「魔女」への恐怖 を大学という知の機関において「科学的」に解決しよ うとする場だった。

科学と想像との融合と拮抗の場, そして進歩と破局 の不可分性を, インゴルシュタット史は象徴している. これが，小説『フランケンシュタイン』のフィクショ ンの想像を支えるものだったのである.

企画の趣旨に合わせ, これらの想像にとって最も重 要な引用で締めくくりたい. 本稿ですでに言及した『フ ランケンシュタイン』のエピグラフの引用である.

創造主よ，土塊（つちくれ）からわたしを人の かたちにつくってくれと頼んだことがあった か?

暗黒からわたしを起こしてくれと，抒願いした ことがあったか？

人工知能が「創造主」にこのように語りかけてくる 未来は，すでに『フランケンシュタイン』によって預 言されていた，人類は自ら創り出した知から発せられ る，この問いに向き合う日は近いだろう。そして，向 き合うための想像力にとって, 本稿で扱った「想像の
歴史」がその助力となるかもしれない.

\section{謝辞}

「インゴルシュタットの不思議」に出会わせてくれた 学生, そして日々の知的刺激を与えてくれる歴史学に 感謝を述べたい.

\section{参 考 文 献}

[1]安川晴基: “『記憶』と『歷史』集合的記憶論における一 つのトポス,”藝文研究, Vol.94, pp. 282-299, 2008.

[2] C. Siebeck: "Erinnerungsorte, Lieux de Mémoire," Docupedia-Zeitgeschichte, Version: 1.0, 2.3.2017: http://docupedia.de/zg/Siebeck_erinnerungsorte_v1_ de 2017?oldid=126408 [accessed July 30, 2018]

[3] 別府昭郎: “近代大学の摇籃一八世紀ドイツ大学史研 究,”知泉書館, p. 101, 2014.

[4] G. Treffer: Ingolstadt. Kleine Stadtgeschichte, Regensburg (Kindle Edition), No.93, p. 2221, 2018.

[5]Ｋ. G. アッポルド, 徳善義和訳: “宗教改革小史,”教文館, pp. 281-296, 2012.

[6] Treffer: a.a.O. No.1290.

[7] 溝井裕一: “ファウスト伝説 一覀魔と魔法の西洋文化史 ," 文理閣, p. 29, 2009.

[8] P. M. Palmer and R. P. More: Sources of the Faust Tradition, Oxford University Press, p.89, 1936.

[9] Ibid., p. 29-30.

[10] Ibid., p. 89.

[11] 溝井: 前掲書, p. 30 .

[12] 小林繁子: “近世ドイッの魔女裁判 民衆世界と支配権 力,”ミネルヴァ書房, 2015.

[13] W. Behringer: "Meinungsbildende Befürworter und Gegner der Hexenverfolgung (15. bis 18. Jahrhundert)," Helfried Valentinitsch (Hrsg.): Hexen und Zauberer. Die grosse Verfolgung - ein europäisches Phänomen in der Steiermark, S.228, 1987.

[14] 小林: 前掲書.

[15] 同上, p. 79.

[16] ウォルフガング:ベーリンガー, 長谷川直子訳: “魔女と魔 女狩り," 刀水書房, pp. 251-261, 2014.

[17] Treffer: a.a.O. No.1272.

[18]木村晶子: “『フランケンシュタイン』における空間,”メア リー・シェリー研究—『フランケンシュタイン』作家の全 体像,鳳書房, p. 56, 2010.

[19] Treffer: a.a.O. No.1282.

[20] 別府: 前掲書, p. 109.

[21] ウルリヒ・イム・ホーフ, 成瀬治訳: “啓蒙のヨーロッパ,”平 凡社, p. 298, 1998.

[22] 同上, p. 299.

[23] 木村: 前揭書, pp. 56-57.

[24] 同上, p. 56.

[25] G. McNiece: Shelley and the Revolutionary Idea, Harvard University Press, pp. 96-99, 1969

[26] Treffer: a.a.O. No.1463.

[27] 田丸理砂: “「女の子」という運動 ワイマール共和国末期 のモダンガール," 春風社, 2015.

[28] 武田悠一: フランケンシュタインとは何か 怪物の倫理学, 彩流社, p. 17, 2014. 
[29] 武田悠一: “序章 フランケンシュタインの子供たち, 増殖 するフランケンシュタイン 批評とアダプテーション," 彩流 社, p. 8, 2017.

[30] 山田夏樹: ロボットとジェンダー『フランケンシュ タイン』、鉄腕アトム』における『不完全』な身体イメ ージ」, 昭和文学研究, Vol.53, pp. 25-37, 2006

[31] 武田: フランケンシュタインとは何か, p. 8.

[32] メアリー・シェリー, 小林章夫訳: “フランケンシュタイン,” 光文社, p. 95, 2010.

[33] 同上, p. 19.

[34] 同上, p. 19

[35] 伸井太一編: “第二帝国 (下),”パブリプ,pp. 4-5, 2017.

[36] ロスビー・スミス: フランケンシュタインと自然の魔力 ス ティーブン•バン編, 遠藤徹訳: “怪物の黙示録『フランケ ンシュタイン』を読む,”青弓社, p. 531997.

[37] シェリー: 前掲書, pp. 86-87.

[38] 同上, p. 90

[39] J. J. ルセルクル, 今村仁司ほか訳: “現代思想で読むフラ ンケンシュタイン,”講談社, p. 31, 1997.

[40] 同上, pp. 88-89.

[41] 大橋博司: パラケルススの生涯と思想, 思索社, p. 37, 1988.

[42] 木村: 前掲書, pp. 58-59.

[43] ルセルクル: 前掲書, p. 31 .

[44] 武田: フランケンシュタインとは何か, pp. 175-177.

[45] ルイス・ジェームズ: 怪物の系譜 純文学と大衆芸術に生 き続けるフランケンシュタインの怪物, p.120.

$$
\text { (2018年8月9日 受付) }
$$

[問い合わせ先]

干167-8585 東京都杉並区善福寺2-6-1

東京女子大学

柳原 伸洋

E-mail: yanagihara0701@gmail.com

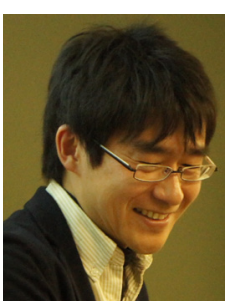

や柳原化佯 [非会員]

2011年東京大学大学院総合文化研究科 単位取得退学. 在ドイツ日本大使館専 門調査員, 東海大学文学部講師を経 て, 現在, 東京女子大学現代教養学部 歴史文化専攻教員. 専攻はドイツ現代 史 (空襲研究). 